\title{
Do Investors Appreciate Information about Corporate Social Responsibility? Evidence from the Polish Equity Market
}

\author{
Agata Adamska, Tomasz J. Dabrowski
}

\author{
Warsaw School of Economics \\ al. Niepodleglosci 162 \\ 02-554 Warsaw, Poland \\ E-mail.agata.adamska@sgh.waw.pl,tomsz.dabrowski@sgh.waw.pl
}

cross $^{\text {ref }}$ http://dx.doi.org/10.5755/j01.ee.27.4.13377

\begin{abstract}
The results of extensive research indicate that there is a positive relation between corporate social responsibility (CSR) and financial results of companies. Investors should focus on the companies which represent high CSR standards. Changes in the level of these standards is important information from investors' point of view because these changes tend to be reflected in the share price and, consequently, in the rate of return. The research applying the event study methodology was conducted to determine how the inclusion or exclusion of the companies operating on the Warsaw Stock Exchange (WSE) from the ethical RESPECT Index affects the rate of return on their shares. The results confirm that investors on emerging markets also take into account the information about changes in the level of corporate social responsibility and respond positively to its growth and negatively to its decline. The same pattern of the invertors' reaction is observed on more mature markets. The obtained results not only contribute to the development of theory, but also have significant practical implications. They show that the presence in the ethical index helps to communicate higher standards of corporate social responsibility. Indicating it to investors may exert an impact on the company's market value.
\end{abstract}

Keywords: Emerging Market, Ethical Index, Event Study, CSR - Corporate Social Responsibility, Information Asymmetry.

\section{Introduction}

When purchasing and selling shares on the capital market, investors take into account all the available information to set their price. According to the market efficiency theory (Fama, 1970; Malkiel, 2003; Malkiel, 2005), it means that a change in available information is immediately reflected in the share price level. The information regarded by investors to be more relevant has stronger impact on the price than information they consider to be less significant. This allows to indirectly determine whether the information is of high or low value for the investors. On the other hand, by activities they undertake, companies communicate their features (Certo et al., 2001; Certo, 2003; Cohen \& Dean, 2005) in an attempt to affect investors' decisions and improve the evaluation of their own assets. As a consequence, they raise their market value. Their success depends on the degree to which the indicated features are regarded important from the perspective of the company evaluation made by investors.

One of the corporate features becoming increasingly significant for different groups of stakeholders is the level of social responsibility. The scientific problem of this article is to analyse the influence of social responsibility on the decisions made by one of the stakeholders groups - the investors. The object of this article is to increase knowledge related to the nature of this influence. The aim of the research is to determine how investors react to changes in the level of social responsibility information, with regard to the companies listed on the Polish capital market. To answer this question the authors conducted a research on how the disclosure of the inclusion or exclusion of a company listed on the Warsaw Stock Exchange from the ethical RESPECT Index influences the rate of return, measured by the change of the price of their shares. The research used an event study method, which is often applied in similar situations (Masse et al., 2000; Consolandi et al., 2008; Ramchander et al., 2012). The novelty is the concentration on the capital market of a post-communist country, where the influence of CSR for investors' decisions is poorly understood. So far this type of research has been conducted primarily on mature markets. To the best of our knowledge, this is the first study that focuses on the European emerging markets, where both the inclusion and exclusion from RESPECT Index were taken into consideration. In the previous research concerning the Polish market, exclusions were omitted due to insufficient number of cases (Daszynska-Zygadlo et al., 2014).

The paper proceeds as follows. The first section presents the causes of the potential interest of investors in the level of corporate social responsibility. The second section describes the RESPECT Index, which is the only ethical index operating on the emerging markets in Europe. The following sections present the event study methodology used in the research, as well as the research itself and its results. The next section, devoted to the detailed discussion of the results, puts their interpretation in the light of the current theory and suggests further research. The article closes with conclusions.

\section{Theoretical Background and Hypotheses}

Corporate social responsibility plays an increasingly significant role (Juscius \& Snieska, 2008). Companies representing higher standards in this area attain a number 
of advantages (Valackiene \& Miceviciene, 2001; Juscius \& Jonikas, 2013). On the other hand, as a result of a low level of social responsibility, some disadvantages show up. The advantages for the company include a chance to distinguish itself on the market (Brammer \& Millington, 2008), constituting the basis for the strategy of differentiation, which allows to achieve competitive advantage in order to maintain long term above-the-average results (Porter, 1985). Moreover, social responsibility is connected with new market opportunities to create an additional corporate growth potential (Porter \& Kramer, 2011). The most important, however, is that CSR is treated as crucial element of goodwill (Fombrun \& Shanley, 1990; Brammer \& Pavelin, 2004; Schnietz \& Epstein, 2005; Siltaoja, 2006; Bertels \& Peloza, 2008; Soppe et al., 2011), which affects the company market value as a component of its intangible assets (Srivastava, 1997; Brown, 1998; Black et al., 2000). It is also stressed that the stakeholders of companies with high CSR standards are ready to provide their capital to them on more favourable terms and at the same time they are less likely to undertake actions against these companies (Fombrun et al., 2000). For the socially irresponsible companies the tendency is contrary.

In the context of the impact of CSR on the stakeholders' conduct, it is generally the customer behaviour that is in the centre of interest. The research results indicate that customers' recognition of the degree of social corporate responsibility affects the evaluation of products offered by companies (Brown \& Dacin, 1997), purchasing intentions (Sen \& Bhattacharya, 2001), the level of acceptable price (Obermiller et al., 2009) and the level of satisfaction (Luo \& Bhattacharya, 2006) or identification with the company (Peloza \& Papania, 2008; Perez, 2009). All these factors exert a direct (purchasing intentions or product price) or indirect (product evaluation, satisfaction and identification) impact on the results achieved by the company. This impact is reflected in the results of research on the relations between social responsibility and financial results. The older review research (Margolis \& Walsh, 2003; Orlitzky et al., 2003) as well as the latest empirical studies (Lev et al., 2010; Barnett \& Salomon, 2012; von Arx \& Ziegler, 2014; Carnevale \& Mazzuca, 2014) indicate a primarily positive impact of CSR on the area of financial results, both from the accounting and the market perspectives. Despite certain doubts regarding methodology of the research within this field (McWilliams \& Siegel, 2000) and opinions that the favourable influence of social responsibility is not universal but company specific (Barnett, 2007), it may be assumed that the tendency to associate higher CSR standards with the achievement of better financial results is sufficiently supported by empirical research.

The benefits derived from positive assessment of corporate social responsibility, especially with regard to reputation and customer behaviour, explain why companies with higher CSR standards are willing to indicate them. On the other hand, a positive impact of social responsibility on financial results is the reason why the CSR area may draw the investors' attention. The standards represented by companies in this area may be treated as a leading indicator of future financial results. Despite the communication of the level of their social responsibility by companies and a potential interest in this level by investors, there is significant information asymmetry between them. This phenomenon is primarily caused by two factors. The first one is a problem connected with the communication itself in the CSR area (Dabrowski, 2011). Although companies use different channels of this communication (Birth et al., 2008), the message is not specific enough (Ferns et al., 2008), which reduces its credibility. The other cause of substantial information asymmetry is a deficit of specialist CSR expertise among investors. Not only do companies possess private information on the actual level of their social involvement but they also have a better expertise on the related issues. On the other hand, investors have to rely on the information provided by companies, which is difficult to verify, evaluate and interpret because they do not have expertise to do it properly. Due to problems connected with the communication of corporate social responsibility on the part of investors and limited access to information combined with a lower level of knowledge on the part of investors, both companies and investors should be interested in the presence of the company in an ethical index. For companies this presence means a credible way to communicate their high CSR standards. Investors may treat the inclusion of the company in an ethical index or the exclusion from it as synthetic information derived from an independent institution. This can make information asymmetry less significant. The company included in the index applies respectively higher standards, while company excluded from it applies lower standards. From investors' point of view, the change in the evaluation of corporate social responsibility may mean that the company is gaining or losing the opportunity to achieve the CSR related benefits, which will affect its future financial results. Therefore, this is an important information, which should influence companies' share price.

The results of research conducted on mature markets prove that events defined as disclosure information on corporate social responsibility have an impact on investors' decisions. This impact is reflected in share price. Both the inclusion of companies in ethical indices or their exclusion from them (Consolandi et al., 2009, Ramachander et al., 2012), as well as the publication of ratings referring to different aspects of corporate social responsibility (Bramer et al., 2009; Aaron et al., 2012), affect the prices of their shares and the rate of return for investors. It may be assumed then, that a similar phenomenon is also found on the Polish market, despite the fact that it belongs to the category of emerging and not mature markets.

Taking into account all the above considerations, the following hypotheses have been put forward:

H1: The announcement of information that the company has been included in an ethical index has a positive effect on the rate of return on its shares.

H2: The announcement of information that the company has been excluded from an ethical index has an adverse effect on the rates of return on its shares.

The verification of these hypotheses will be based on the analysis of the rates of return on companies' shares included in or excluded from the ethical RESPECT Index in the years 2009-2014. 


\section{Characteristics of the RESPECT Index}

The RESPECT Index was established by the Warsaw Stock Exchange in cooperation with external partners. It includes incomes from the dividend and rights issue. It has been published since November 2009, being the first and so far the only ethical index on the emerging markets in Europe. The index includes the companies whose shares are quoted on the WSE main market and which are characterized by high standards of corporate governance, natural environment impact and social involvement.

The methods of selection of companies for the index, their evaluation and the frequency of index revision have been subject to change. Initially, until 2011 the index revision was made annually, in the years 2011-2012 semiannually, and since 2013 it returned to annual revisions.
The RESPECT Index is an open index, with variable number of companies. In the course of revision, new companies may be added to the index or those listed may be excluded, which raises or reduces the number of companies in the index. As a result of the revision a new composition is published, but the causes of changes (e.g. exclusion motives) or results of the company evaluation are not disclosed nor published. There have been exclusions of companies in between revisions, due to extraordinary occurrences (for example company bankruptcy or merger). These exclusions were not related to the level of the company's social responsibility. Table 1 shows the chronology of changes in the index composition and the number of companies it consisted of, in subsequent periods.

Table 1

Schedule of Changes in the RESPECT Index Composition in the Years 2009-2014

\begin{tabular}{|c|l|c|}
\hline Date of change of Index & \multicolumn{1}{|c|}{ Cause of change } & Number of companies in the Index \\
\hline $27 / 11 / 2009$ & Index revision & 16 \\
\hline $31 / 01 / 2011$ & Index revision & 16 \\
\hline $05 / 04 / 2011$ & Exclusion of one company due to the lack of minimum free float & 22 \\
\hline $01 / 08 / 2011$ & Index revision & 23 \\
\hline $01 / 02 / 2012$ & Index revision & 22 \\
\hline $20 / 04 / 2012$ & Exclusion of one company due to the lack of minimum free float & 21 \\
\hline $18 / 06 / 2012$ & Exclusion of one company due to filing for bankruptcy & 20 \\
\hline $31 / 07 / 2012$ & Index revision & 19 \\
\hline $28 / 12 / 2012$ & Exclusion of one company due to the planned merger with another company & 20 \\
\hline $31 / 01 / 2013$ & Index revision & 23 \\
\hline $20 / 12 / 2013$ & Index revision & 24 \\
\hline $19 / 12 / 2014$ & Index revision & \\
\hline
\end{tabular}

Source: Messages of the Warsaw Stock Exchange Board

The RESPECT index revision is based on a threestage analysis. The first stage identifies the companies with the best liquidity within indices WIG20, mWIG40 and sWIG80. In the second stage these companies are evaluated with regard to the quality of governance and the relations with investors. The issue of sanctions imposed by the regulator (the Financial Supervision Authority) or the Exchange is examined, and penalized entities are eliminated. The publication of all information required by regulators is also evaluated, including the quality of current reports and the compliance of website with the Exchange guidelines, including the use of website to communicate with investors within investor relations. The analysis is based on generally accessible sources. The third, last stage includes the evaluation of the corporate social responsibility with reference to environmental, social and managerial criteria, as well as customer relations. The evaluation is made on the basis of information acquired from the questionnaires, which are filled up by companies. This information is verified by an independent organization (auditor), which is a WSE partner co-participating in the index revision. The evaluation made at the third stage closes the whole procedure and determines the ultimate composition of companies in the index after the revision.

\section{Corporate Social Responsibility and the Rate of Return on Shares. An Event Study Methodology}

An event study methodology has been extensively used in a vast number of research on market reaction to information on different events, referring to the market as a whole or to individual companies (Doukas \& Li, 2009). It was used to examine negative (Cox \& Means 1999; Cox \& Weirich, 2002) as well as positive information (Ramasesh 1998). The method of event study was used to analyse the effects of publishing financial information on share splits, announcement of dividend payment (Crawford et al., 2005), disclosure of surprising financial results (not in line with forecasts) (Deshpande \& Svetina 2011), and also to information on the reputation of companies (Abraham et al. 2008). This method was used in the research devoted to the impact of the information on the inclusion of companies in stock exchange indices or exclusion of them from these indices (Masse et al., 2000; Geppert et al., 2011), in particular from ethical indices (Consolandi et al., 2008). Such a wide range of research indicates that the method is universal and confirms that its application to analyse investors' reaction to information of the inclusion of companies in or excluding them from the RESPECT Index is feasible. 
The method of event study identifies economic effects of an event through estimation of its impact on the price of shares, what subsequently affects the rate of return on shares. The method is based on the assumption of market efficiency, according to which every event which affects future financial results of the company is immediately reflected in the price of its shares. The method of event window makes a comparison of the real level of rate of return, affected by the analysed event, with the expected rate of return that would be achieved even if this event would never have occurred. In our research we define the event as a disclosure of information about a company inclusion in or exclusion from the RESPECT Index. We considered all the inclusions and exclusions effected during the index revision in the whole period of its operation, i.e. 2009-2014. We omitted the exclusions caused by bankruptcy (one case) and mergers (one case). We also omitted two exclusions of companies resulting from the decrease in their free float below the minimum level acceptable for the companies in the index. Too low free float also caused the exclusion of both of the companies mentioned from other indices. All these cases were not taken into account, as it was impossible to isolate the effect of the exclusion of these companies from the RESPECT Index from the effect of other events. The analysed population totaled to 41 included and 13 excluded companies, with the four aforementioned omitted companies not having been taken into account. The time breakdown is presented in Table 2 .

Time Breakdown and Number of Cases to Analyse with the Event Study Method

\begin{tabular}{|c|c|c|c|c|c|c|c|c|}
\hline Date of event & 20/11/2009 & 25/01/2011 & 14/07/2011 & 31/01/2012 & 31/07/2012 & 24/01/2013 & 17/12/2013 & 18/12/2014 \\
\hline Number of companies included in the index & 16 & 5 & 7 & 4 & 1 & 1 & 4 & 3 \\
\hline Number of companies excluded from the index & 0 & 5 & 0 & 3 & 2 & 0 & 1 & 2 \\
\hline
\end{tabular}

Source: authors' own calculations

In addition to the identification of the analysed population, it was also important to determine the size of the event study window. A similar research on the inclusion and exclusion with reference to the DJSI Stoxx Index (Consolandi et al., 2008) assumes the division of the event study window into three parts: the period before the publication, the period before the change, and the period after the change. This division appeared to be not feasible in the analysis of changes in the RESPECT Index, because the WSE Board has not implemented uniform policy on the timing of disclosing this information to the market. The time from the moment of disclosure of the index composition varied from several hours in July 2012 up to two weeks and a half in July 2011. Time gaps between the date of publication of information on index revision and the implementation of changes are presented in Table 3. Due to a different duration of this time gap, we assumed the date of the publication of index composition as a reference day. As a result two sub-periods were isolated: before and after the disclosure of this information. This solution was also supported by the fact that the RESPECT Index is not an index used in trade, i.e. the actual inclusion of the company in the Index does not result in price changes of any financial instruments. A possible price creating role is played by the information itself, and not by the implementation of composition change.

Table 3

Time Gap between the Announcement of Changes in the Index and Their Implementation

\begin{tabular}{|c|c|c|c|c|c|c|c|c|}
\hline Date of publication of information & $20 / 11 / 2009$ & $25 / 01 / 2011$ & $14 / 07 / 2011$ & $31 / 01 / 2012$ & $31 / 07 / 2012$ & $24 / 01 / 2013$ & $17 / 12 / 2013$ & $18 / 12 / 2014$ \\
\hline Date of index change & $27 / 11 / 2009$ & $31 / 01 / 2011$ & $01 / 08 / 2011$ & $01 / 02 / 2012$ & $31 / 07 / 2012$ & $31 / 01 / 2013$ & $20 / 12 / 2013$ & $19 / 12 / 2014$ \\
\hline Time gap (in days) & 7 & 6 & 18 & 1 & 0 & 7 & 3 & 1 \\
\hline
\end{tabular}

Source: authors' own calculations

Another element to determine was the event window length. The research conducted so far shown considerably diversification in this respect. The periods analysed so far have been very short: from one or two days (Abraham et al., 2008), thorough several or several dozen days (Consolandi et al., 2008, Masse et al., 2000), to up to 250 days (Anderson \& Smith, 2006). Due to the lack of unanimity in this area, researchers may determine the event window length on their own. We decided that the market reaction should be analysed within 5 days after the information disclosure and the reference period was stipulated to be 5 days before this event. It was assessed that a period of 5 days after publishing the information is long enough so that it could reach investors and affect their decisions, and at the same time sufficiently short to eliminate the risk of appearance of other price creating information in the meantime.
The analysis of the degree of market response to positive and negative information on the level of corporate social responsibility was made through the measurement of abnormal rate of return (ARR), calculated according to the following formula:

$$
A R R_{i t}=R_{i t}-E\left(R_{i t}\right)
$$

where $R_{i t}$ is a real rate of return on shares $i$ in period $t$, and $E\left(R_{i t}\right)$ is the value of the expected rate of return in the case of the lack of information about an inclusion in or exclusion from the RESPECT Index. The expected value was estimated with the use of CAPM model, which is often applied in such situations. According to the CAPM model:

$$
E\left(R_{i t}\right)=R_{f t}+\beta_{i}\left(R_{m t}-R_{f t}\right)
$$

where $R_{f t}$ is the risk free rate of return in period t (This value was represented by the market rate of return on Polish Treasury bonds with shortest expiry period, and 
since the middle of 2012 the market rate of zero coupon bonds with the shortest expiry period. The change resulted from the expiry of the last series of Treasury bonds in March 2012 - there were no further issues of this instrument.). $R_{m t}$ is a rate of return on the market portfolio (in this case WIG index serves as a market portfolio), coefficient beta $\beta_{i}$ is a risk measure of share $i$, estimated on the basis of measurements taken in the period of 60 days preceding the event. The value of coefficient beta $\beta_{i}$ is the relation of covariance of the asset with the market portfolio to the variance of the market portfolio itself. It was calculated according to the formula:

$$
\beta_{i}=\frac{\operatorname{cov}\left(R_{i}, R_{m}\right)}{\sigma_{R_{m}}^{2}}
$$

Assuming that the market is efficient, the abnormal rate of return is to be treated as the event effect. In order to check whether there is a systematic deviation of this rate from 0 , a cumulated abnormal rate of return on every share $\left(C A R R_{i}\right)$ was calculated for the period of before and after the announcement of the index revision. The following formula was used:

$$
C A R R_{i}=\prod_{t=1}^{n}\left(1+A R R_{t i}\right)-1
$$

On the basis of cumulated abnormal rates of return in two sub-periods (before and after the announcement of information about the changes in the index) we calculated the average for each group of companies: included and excluded from the index. Subsequently these values in all four analysed groups were subject to parametric tests. It was examined whether the average cumulated rate of return in the period is equal to 0 (bilateral test). The results are presented in Table 4.

Table 4

Cumulated Abnormal Rate of Return on Shares Included in and Excluded from the RESPECT Index in the Years 2009-2014

\begin{tabular}{|c|c|c|c|c|}
\hline & \multicolumn{2}{|c|}{ Companies included in the Index } & \multicolumn{2}{c|}{ Companies excluded from the Index } \\
\hline 5-day period & CARR & Test statistics: t(40) & CARR & Test statistics: t(12) \\
\hline before info & -0.0241 & $-2.64574^{* *}$ & -0.0225 & $-1.37306^{\mathrm{x}}$ \\
\hline after info & 0.0101 & $2.00004^{*}$ & -0.0192 & $-1.43685^{\mathrm{x}}$ \\
\hline
\end{tabular}

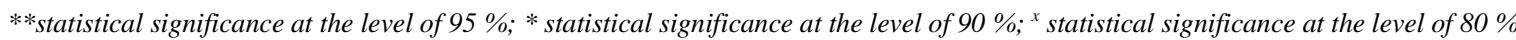
Source: authors' own calculations

The obtained results came up to the expectations. In the case of companies included in the index, the CARR variable in the period of 5 days after the announcement of the information had a positive value and was statistically relevant. It means that the announcement of this information positively affected the abnormal rate of return as assumed in H1. With reference to companies excluded from the index, the CARR variable had a negative value, being also statistically relevant. This relevance was at a slightly lower level, due to smaller population of companies. The obtained result indicates a negative impact of the information about exclusion on the abnormal rate of return on shares of companies excluded from the index, which is compliant with the predictions presented in $\mathrm{H} 2$. The asymmetry of changes in abnormal rates of return was also seen; a positive CARR value amounted to a little over $1 \%$, and a negative value to nearly $2 \%$. Thus, the market response to positive information was weaker than to negative one. Investors punish companies which have not met their expectations in the CSR area to a larger extent than reward them for achieving higher standards in this area.

\section{Discussion}

The considerations presented in the article refer to three very important issues. The first one is the problem of market efficiency, meaning that every new public information is immediately reflected in share prices. The obtained results indicate that the Polish capital market is efficient in a sense that it reflects such events as the inclusion of a company in the index or its exclusion from the index in the share price.

The second issue referred is the importance of the level of corporate social responsibility from the investors' point of view. According to the resource-based theory (Hall,
1992; Hall, 1993; Surroca et al., 2010) it is intangible assets, like goodwill, and according to the stakeholder theory (Freeman, 1984; Jones, 1995) it is stakeholders' behaviour, that relate financial results to corporate social responsibility. Therefore investors should treat the level of corporate social involvement as a predictor of their future financial results and pay attention to the information indicating changes in this area. The results obtained in the research prove that investors highly appreciate the information about corporate social responsibility and respond positively to the events proving companies' high standards in this area, and negatively to the information about the lowering of these standards. Furthermore, it appeared that the negative response is stronger than the positive response. It is in line with the results of other research, which indicates that investors punish socially irresponsible companies more than they reward those socially responsible (Ramchander et al., 2012). The fact that investors pay attention to the information about the level of corporate social responsibility also indicates that communicating this feature by companies may influence their market value.

The third issue concerned possible differences in vulnerability to CSR problems among investors on the mature and emerging markets in Europe. While there is plentiful research on the impact of corporate social responsibility on investors' decision on the mature markets (Brammer \& Millington, 2008; Consolandi et al., 2008, Ramchander et al., 2012), there is a shortage of research in this area with reference to emerging markets. The results presented in this article fill in this gap, expanding the knowledge of investors' preferences on these markets. These results indicate that also investors on emerging markets are vulnerable to information on corporate social responsibility and respond in a similar manner as investors on mature markets. 
In our research we analysed the impact of public information reporting the change in the level of corporate social responsibility on the rate of return on shares. The consequence of the concentration on the moment of announcement of the information was a short time horizon of the event window. Further research may be aimed to determine whether the identified impact of changes in the level of corporate social responsibility on the rate of return on shares is permanent. It would require the lengthening of the time horizon of the event window. An attempt to scrutinize the response of emerging markets investors to other events reflecting corporate social responsibility, in addition to inclusions or exclusions from the ethical index, may also be an interesting research direction to follow. The publication of a CSR related rating or reward granted to the company may become good examples of such events.

\section{Conclusions}

There has been discussion in the literature about the impact of corporate social responsibility on financial results and the significance of CSR from investors' point of view. Opponents of corporate social responsibility have pointed out many threats arising from it (Friedman, 1962; Friedman, 1970; Jensen, 2001), while supporters have emphasized its positive impact on economic performance of the company. One of the main questions asked within this discussion is about the response of investors to events indicating changes in the level of corporate social responsibility. The research results of the study presented in this article show that on emerging markets investors respond positively to the information about the growth of social engagement and negatively to the information about its decline. Thus, the results prove the hypotheses formulated in the article and support the position of proponents of corporate social responsibility. Investors consider information about the social commitment of the companies as valuable, most probably because they regard it as a predictor of future economic performance. They can expect an improvement of the financial results in the companies that are more socially responsible and their deterioration in the case of those less socially responsible. Thus, this article is filling one of the gaps in this particular scientific area. The results obtained show also that information on the increase and the decline of social involvement is treated in different manner. Growth of such involvement has a weaker influence on investors' decisions, and the decline has stronger impact. One of possible explanations of this phenomenon can be the human mind tendency to assign greater importance to the bad things than to the good things, as known from the psychology (Baumeister et al., 2001). The findings presented in this article also indicate that investors in the Polish market are not fundamentally different from investors in more mature markets, since their reaction patterns to the information about changes in the level of social responsibility of companies are similar.

\section{References}

Aaron J. R., McMillan A., \& Cline B. N. (2012). Investor Reaction to Firm Environmental Management Reputation. Corporate Reputation Review, 15(4), 305-318. http://dx.doi.org/10.1057/crr.2012.15

Abraham, S. E., Friedman, B., Khan, R. H., \& Skolnik, R. (2008). Is Publication of the Reputation Quotient (RQ) Sufficient to Move Stock Prices?. Corporate Reputation Review, 11(4), 308-319. http://dx.doi.org/10.1057/ crr.2008.26

Anderson, J., \& Smith, G. (2006). A Great Company Can Be a Great Investment. Financial Analysts Journal, 62(4), 8693. Available from internet: http://dx.doi.org/10.2469/faj.v62.n4.4189

Barnett, M. L. (2007). Stakeholder Influence Capacity And The Variability Of Financial Returns To Corporate Social Responsibility. Academy of Management Review, 32(3), 794-816. Available from internet: http://dx.doi.org/10. 5465/amr.2007.25275520

Barnett, M. L., \& Salomon, R. M. (2012). Does it Pay to be Really Good? Addressing the Shape of the Relationship between Social and Financial Performance. Strategic Management Journal, 33(11), 1304-1320. Available from internet: http://dx.doi.org/10.1002/smj.1980

Baumeister, R. F., Bratslavsky, E., Finkenauer, C., \& Vohs K. D. (2001). Bad Is Stronger Than Good. Review of General Psychology, 5(4), 323-370. Available from internet: http://dx.doi.org/10.1037/1089-2680.5.4.323

Bertels, S., \& Peloza, J. (2008). Running Just to Stand Still? Managing CSR Reputation in an Era of Ratcheting Expectations. Corporate Reputation Review, 11(1), 56-72. http://dx.doi.org/10.1057/crr.2008.1

Birth, G., Illia, L., Lurati, F., \& Zamparini, A. (2008). Communicating CSR: Practices among Switzerland's top 300 companies. Corporate Communications: an International Journal, 13(2), 182-196. http://dx.doi.org/10.1108/13563280810869604

Black, E. L., Carnes, T. A., \& Richardson, V. J. (2000). The Market Valuation of Corporate Reputation. Corporate Reputation Review, 3(1), 31-42. http://dx.doi.org/10.1057/palgrave.crr.1540097

Brammer, S., \& Millington, A. I. (2008). Does it pay to be different? an analysis of the relationship between corporate social and financial performance. Strategic Management Journal, 29(12), 1325-1343. Available from internet: http://dx.doi.org/10.1002/smj.714 
Brammer, S., \& Pavelin, S. (2004). Building a good reputation. European Management Journal, $22(6), 704-713$. Available from internet: http://dx.doi.org/10.1016/j.emj.2004.09.033

Brown, B. (1998). Do Stock Market Investors Reward Companies with Reputations for Social Performance?. Corporate Reputation Review, 1(3), 271-280. http://dx.doi.org/10.1057/palgrave.crr.1540048

Brown, T. J., \& Dacin, P. A. (1997), The Company and the Product: Corporate Associations and Consumer Product Responses. Journal of Marketing, 61(1), 68-84. Available from internet: http://dx.doi.org/10.2307/1252190

Carnevale, C., \& Mazzuca, M. (2014), Sustainability Report and Bank Valuation: Evidence from European Stock Markets. Business Ethics: A European Review, 23(1), 69-90. Available from internet: http://dx.doi.org/ 10.1111/beer.12038

Certo, S. T. (2003). Influencing initial public offering investors with prestige: Signaling with board structures. Academy of Management Review, 28(3), 432-446. Available from internet: http://dx.doi.org/10.5465/amr.2003.10196754

Certo, S. T., Daily, C. M., \& Dalton, D. R. (2001). Signaling Firm Value through Board Structure: An Investigation of Initial Public Offerings. Entrepreneurship Theory and Practice, 26(2), 33-50.

Cohen, B. D., \& Dean, T. J. (2005). Information asymmetry and investor valuation of IPOs: Top management team legitimacy as a capital market signal. Strategic Management Journal, 26(7), 683-690. Available from internet: http://dx.doi.org/10.1002/smj.463

Consolandi, C., Jaiswal-Dale, A., Poggiani, E., \& Vercelli, A., (2009). Global Standards and Ethical Stock Indexes: The Case of the Dow Jones Sustainability Stoxx Index. Journal of Business Ethics, 87(1), 185-197. Available from internet: http://dx.doi.org/10.1007/s10551-008-9793-1

Cox, R. A. K., \& Means, D. B. (1999). The capital market reaction to lawsuits: Some additional evidence. International Journal of Commerce and Management, 9(1/2), 45-58. http://dx.doi.org/10.1108/eb047382

Cox, R. A. K., \& Weirich, T. R. (2002). The stock market reaction to fraudulent financial reporting. Managerial Auditing Journal, 17(7), 374-382. http://dx.doi.org/10.1108/02686900210437471

Crawford, D., Franz, D. R., \& Lobo, G. J. (2005). Signaling Managerial Optimism through Stock Dividends and Stock Splits: A Reexamination of the Retained Earnings Hypothesis. Journal of Financial and Quantitative Analysis, 40(3), 531-561. Available from internet: http://dx.doi.org/10.1017/s0022109000001861

Daszynska-Zygadlo, K., Ryszawska, B., Slonski, T., \& Zawadzki, B. M. (2014). Investors' Reactions for Sustainability Index Inclusion - Is CSR a Good News?. Folia Oeconomica, 2(300), 45-60.

Dabrowski, T. (2011). Use of cause-related marketing as an example of innovation in communicating corporate social responsibility. In: B. Dobiegala-Korona, P. Masiukiewicz (Eds.). Innovations in customer value creation, pp. 185206, Warsaw: Oficyna Wydawnicza SGH

Deshpande, S., \& Svetina, M. (2011). Does Local News Matter to Investors?. Managerial Finance, 37(12), 1190-1212. http://dx.doi.org/10.1108/03074351111175092

Doukas, J. A., \& Li, M. (2009). Asymmetric asset price reaction to news and arbitrage risk. Review of Behavioral Finance, 1(1/2), 23-43. http://dx.doi.org/10.1108/19405979200900002

Fama, E. F. (1970). Efficient Capital Markets: A Review of Theory and Empirical Work. Journal of Finance, 25(2), 383417. Available from internet: http://dx.doi.org/10.2307/2325486

Ferns, B., Emelianova, O., \& Sethi, S. P. (2008). In His Own Words: The Effectiveness of CEO as Spokesperson on CSRSustainability Issues Analysis of Data from the Sethi CSR Monitor. Corporate Reputation Review, 11(2), $116-129$. http://dx.doi.org/10.1057/crr.2008.11

Fombrun, C., Gardberg, N., \& Barnett, M. (2000). Opportunity platforms and safety nets: Corporate citizenship and reputational risk. Business and Society Review, 105(1), 85-106. http://dx.doi.org/10.1111/0045-3609.00066

Fombrun, C. J., \& Shanley, M. (1990). What's in a name? Reputation building and corporate strategy. Academy of Management Journal, 33(2), 233-258. Available from internet: http://dx.doi.org/10.2307/256324

Freeman, R. E. (1984). Strategic management: A stakeholders approach, Boston: Pitman

Friedman, M. (1962). Capitalism and freedom. University of Chicago Press, Chicago.

Geppert, J. M., Ivanov, S. I., \& Karels, G. V. (2011). An examination of the information content of S\&P 500 index changes: Analysis of systematic risk. Review of Accounting and Finance, 10(4), 411-426. http://dx.doi.org/ $10.1108 / 14757701111185353$

Hall, R. (1992). The Strategic Analysis of Intangible Resources. Strategic Management Journal, $13(2), 135-144$. Available from internet: http://dx.doi.org/10.1002/smj.4250130205 
Agata Adamska, Tomasz J. Dabrowski. Do Investors Appreciate Information about Corporate Social Responsibility?...

Hall, R. (1993). A Framework Linking Intangible Resources and Capabilities to Sustainable Competitive Advantage. Strategic Management Journal, 14(8), 607-618. Available from internet: http://dx.doi.org/10.1002/smj.4250140804

Jensen, M. C. (2001). Value Maximization, Stakeholder Theory, and the Corporate Objective Function. Journal of Applied Corporate Finance, 14(3), 8-21. Available from internet: http://dx.doi.org/10.1111/j.1745-6622. 2001.tb00434.x

Jones, T. M. (1995). Instrumental Stakeholder Theory: A Synthesis of Ethics and Economics.Academy of Management Review, 20(2), 404-437. Available from internet: http://dx.doi.org/10.5465/amr.1995.9507312924

Juscius, V., \& Snieska, V. (2008). Influence of Corporate Social Responsibility on Competitive Abilities of Corporations. Inzinerine Ekonomika-Engineering Economics, 3(58), 34-44. Available from internet: http://www.inzeko.ktu.lt/ index.php/EE/ article/view/ 11541/6222

Juscius, V., \& Jonikas, D. (2013). Integration of CSR into Value Creation Chain: Conceptual Framework. Inzinerine Ekonomika-Engineering Economics, 24(1), 63-70. Available from internet: http://www.inzeko.ktu.lt/index.php/ EE/article/view/2016

Lev, B., Petrovits, C., \& Radhakrishnan, S. (2010). Is doing good good for you? How corporate charitable contributions enhance revenue growth. Strategic Management Journal, 31(2), 182-200. Available from internet: http://dx.doi.org/10.1002/smj.810

Luo, X., \& Bhattacharya, C. B. (2006). Corporate Social Responsibility, Customer Satisfaction, and Market Value. Journal of Marketing, 70(4), 1-18. Available from internet: http://dx.doi.org/10.1509/jmkg.70.4.1

Malkiel, B. (2005). Reflections on the Efficient Market Hypothesis: 30 Years Later. The Financial Review, 40(1), 1-9. Available from internet: http://dx.doi.org/10.1111/j.0732-8516.2005.00090.x

Malkiel, B. G. (2003). The Efficient Market Hypothesis and Its Critics. Journal of Economic Perspectives, 17(1), 59-82. Available from internet: http://dx.doi.org/10.1257/089533003321164958

Margolis, J., \& Walsh, J. (2003). Misery loves companies: Rethinking social initiatives by business. Administrative Science Quarterly, 48(2), 268-305. Available from internet: http://dx.doi.org/10.2307/3556659

Masse, I., Hanrahan, R., Kushner, J., \& Martinello, F. (2000). The Effect of Additions to or Deletions from the TSE 300 Index on Canadian Share Prices. Canadian Journal of Economics, 33(2), 341-359. Available from internet: http://dx.doi.org/10.1111/0008-4085.00019

McWilliams A., \& Siegel D. (2000), Corporate social responsibility and financial performance: Correlation or misspecification?, Strategic Management Journal, 21(5), 603-609. Available from internet: http://dx.doi.org/10. 1002/(sici) 1097-0266(200005)21:5<603::aid-smj101>3.0.co;2-3

Obermiller, C., Burke, C., Talbott, E., \& Green, G. P. (2009). 'Taste great or more fulfilling': The effect of brand reputation on consumer social responsibility advertising for fair trade coffee. Corporate Reputation Review, 12(2), $159-176$. http://dx.doi.org/10.1057/crr.2009.11

Orlitzky, M., Schmidt, F., \& Rynes, S. (2003). Corporate social and financial performance: A meta-analysis, Organization Studies, 24(3), 403-441. Available from internet: http://dx.doi.org/10.1177/0170840603024003910

Peloza, J., \& Papania, L. (2008). The Missing Link Between Corporate Social Responsibility and Financial Performance: Stakeholder Salience and Identification. Corporate Reputation Review, 11(2), 169-181. http://dx.doi.org/10. 1057/crr.2008.13

Perez, R. C. (2009). Effects of Perceived Identity Based on Corporate Social Responsibility: The Role of Consumer Identification with the Company. Corporate Reputation Review, 12(2), 177-191. http://dx.doi.org/10.1057/ crr.2009.12

Porter, M. E. (1985). Competitive Advantage: Creating and Sustaining Superior Performance. New York: Free Press.

Porter, M. E., \& Kramer, M. R. (2011). Creating Shared Value. How to reinvent capitalism — and unleash a wave of innovation and growth. Harvard Business Review, 89(1), 2-17.

Ramasesh, R. V. (1998). Baldrige Award announcement and shareholder wealth. International Journal of Quality Science, 3(2), 114-125. http://dx.doi.org/10.1108/13598539810211950

Ramchander, S., Schwebach, R. G., \& Staking, K. (2012). The informational relevance of corporate social responsibility: evidence from DS400 index reconstitutions. Strategic Management Journal, 33(3), 303-314. Available from internet: http://dx.doi.org/10.1002/smj.952

Schnietz, K. E., \& Epstein, M. J. (2005), Exploring the Financial Value of Reputation for Corporate Responsibility During a Crisis, Corporate Reputation Review, 7(4), 327-345. http://dx.doi.org/10.1057/palgrave.crr.1540230 
Sen, S., \& Bhattacharya, C. B. (2001), Does Doing Good Always Lead to Doing Better? Consumer Reactions to Corporate Social Responsibility. Journal of Marketing Research, 38(2), 225-243. Available from internet: http://dx.doi.org/10. 1509/jmkr.38.2.225.18838

Siltaoja, M. E. (2006). Value Priorities as Combining Core Factors between CSR and Reputation - A Qualitative Study. Journal of Business Ethics, 68(1), 91-111. Available from internet: http://dx.doi.org/10.1007/s10551-006-9042-4

Soppe, A. B. M., Schauten, M. B. J., Soppe, J., \& Kaymak, U. (2011). Corporate Social Responsibility Reputation (CSRR): Do Companies Comply to their Raised CSR Expectations?, Corporate Reputation Review, 14(4), $300-323$. http://dx.doi.org/10.1057/crr.2011.21

Srivastava, R. A., McInish, T. H., Wood, R. A., \& Capraro A. J. (1997). The Value of Corporate Reputation: Evidence from the Equity Markets. Corporate Reputation Review, 1(1/2), 75-79.

Surroca, J., Tribo, J., \& Waddock, S. (2010). Corporate Responsibility and Financial Performance: the role of Intangible Resources. Strategic Management Journal, 31(5), 463-490. Available from internet: http://dx.doi.org/10. $1002 /$ smj. 828

Valackiene A., \& Miceviciene D. (2011). Methodological Framework Analysing a Social phenomenon: Stakeholder Orientation Implementing Balanced Corporate Social Responsibility. Inzinerine Ekonomika-Engineering Economics, 22(3), 300-308. Available from internet: http://www.inzeko.ktu.lt/index.php/EE/article/view/520/845. http://dx.doi.org/10.5755/j01.ee.22.3.520

Von Arx, U., \& Ziegler, A. (2014). The Effect of CSR on Stock Performance: New Evidence for the USA and Europe. Quantitative Finance 14 (6), 977-991. Available from internet: http://dx.doi.org/10.1080/14697688.2013.815796

The article has been reviewed.

Received in October, 2015; accepted in October, 2016. 